\title{
Response of aquatic bacterial populations to substrate enrichment
}

\author{
Tom Berman ${ }^{1}$, Hans-Georg Hoppe ${ }^{2}$, Klaus Gocke ${ }^{2}$
}

\author{
${ }^{1}$ Kinneret Limnological Laboratory, Israel Oceanographic \& Limnological Research, PO Box 345, Tiberias, Israel 14102 \\ ${ }^{2}$ Institut für Meereskunde an der Universität Kiel, Abt. Marine Mikrobiologie, Düsternbrooker Weg 20, D-24105 Kiel, Germany
}

\begin{abstract}
The responses of natural bacterial populations in the waters of the Kiel Fjord, Germany, and in Lake Kinneret, Israel, to additions of organic substrates were followed by determining changes over $24 \mathrm{~h}$ either in direct cell counts or in ${ }^{3} \mathrm{H}$-thymidine incorporation, and in the Kiel Fjord additionally in ${ }^{3} \mathrm{H}$-leucine incorporation. In parallel, $1 \mu \mathrm{m}$ filtered water samples were stored for 3 or $4 \mathrm{~d}$ in order to starve the indigenous bacterial populations prior to repeating the substrate addition experiments. Generally, upon substrate addition, relatively higher incorporation of radiotracers was noted in the preincubated samples. Growth response to substrate addition even in starved populations was only significant after $24 \mathrm{~h}$. Incorporation rates of ${ }^{3} \mathrm{H}$-thymidine and ${ }^{3} \mathrm{H}$-leucine were more sensitive indicators of bacterial response to substrate additions than cell counts. Continued cell replication in unsupplemented controls, and insignificant increase over time of radiotracer incorporation in most of the fresh samples with added supplements, indicated that the indigenous bacterial populations in Kiel Fjord and Kinneret were apparently not substrate limited. Comparison of actual bacterial production after $24 \mathrm{~h}$ (direct counts) to that predicted by ${ }^{3} \mathrm{H}$-thymidine incorporation after $1 \mathrm{~h}$ showed that although reasonably good predictions of daily production were obtained in the unsupplemented samples, this was usually not the case when substrates were added.
\end{abstract}

KEY WORDS: Bacterial growth - Substrate responses - Kiel Fjord - Lake Kinneret

\section{INTRODUCTION}

There is general agreement that bacteria play a fundamental role in regulating the flux of material in aquatic systems (Azam \& Cho 1987) but quantifying both bacterial biomass and activity has proved difficult. Probably the most widely used method to estimate bacterial production in aquatic systems at present is the ${ }^{3} \mathrm{H}$-thymidine uptake technique, pioneered by Fuhrman \& Azam (1982) and subsequently modified by many workers (e.g. Wicks \& Robarts 1987). Other methods based on the incorporation of ${ }^{3} \mathrm{H}$-adenine (Karl 1982) and, more recently, ${ }^{3} \mathrm{H}$-leucine (Kirchman et al. 1985, Simon \& Azam 1989) have also been used to determine bacterial growth rates in nature.

The ${ }^{3} \mathrm{H}$-thymidine and ${ }^{3} \mathrm{H}$-leucine methods are operationally simple to carry out. For both these methods, however, there are considerable difficulties in relating the particle-associated radioactivity retained on filters to actual bacterial growth rates, i.e. as changes either in terms of bacterial cell numbers or of bacterial carbon per unit time. Many of the problems associated with these assays have been discussed (e.g. Hollibaugh 1988, Smits \& Riemann 1988) but attempts to arrive at definitive protocols and a general consensus on the value of conversion factors have not yet been successful.

Even though the determination of actual in situ bacterial growth rates using radioisotope incorporation is problematic, these techniques could be useful to follow relative changes in natural bacterial populations. For example, upon addition of a suitable organic substrate, bacteria under growth limitation might show an increase of radioisotope incorporation with time in comparison to unsupplemented controls. Therefore, the incorporation of ${ }^{3} \mathrm{H}$-thymidine or ${ }^{3} \mathrm{H}$-leucine in samples of supplemented and unsupplemented natural waters after an appropriate incubation period should be indicative of the nutritional and/or physiological state of the initial bacterial populations. 
Here we describe a series of experiments in which we examined the response of the indigenous bacterial populations in the Kiel Fjord (Germany) and in Lake Kinneret (Israel) to the addition of organic substrates which were presumed to be readily utilizable. Our purpose was 3-fold. First, we wished to determine whether ${ }^{3} \mathrm{H}$-thymidine or ${ }^{3} \mathrm{H}$-leucine incorporation could be used to indicate bacterial substrate limitation in situ. This question appeared important to us because there is some indication that 'nutrient insufficiency is the most common environmental extreme to which microorganisms are routinely exposed' (Tempest \& Neijssel 1981, cited from Harder \& Bijkhuizen 1983). Second, we wanted to measure how rapidly and with what intensity the native bacterial populations would respond to a pulse of high concentrations of organic substrates. Third, we wished to determine how well the observed production of bacteria during $1 \mathrm{~d}$ of incubation was reflected by 'predicted' production as calculated on the basis of initial ${ }^{3} \mathrm{H}$-thymidine (and, in Kiel water, ${ }^{3} \mathrm{H}$-leucine) uptake, in supplemented as well as unsupplemented samples.

\section{METHODS}

Kiel Fjord. Two experiments were performed using water taken from the surface of the Kiel Fjord (a eutrophic brackish region of the western Baltic Sea Lenz 1977) on 8 and 20 September 1991. After prefiltration through a $20 \mu \mathrm{m}$ net, the samples were passed by gravity through a $1 \mu \mathrm{m}$ Nuclepore filter to remove most of the plankton other than bacteria and $500 \mathrm{ml}$ portions were distributed into six 11 , stoppered flasks. Additions of the following substrates, at final concentrations of $10 \mu \mathrm{M}$, were made to the experimental flasks: glucose, aspartic acid, alanine, alanine tripeptide (ala-3) and cellobiose. A control flask remained unsupplemented. These compounds were chosen to cover a range of substrates presumed to be readily available for bacterial growth. The levels of added substrate concentration were much higher than their anticipated concentrations in the Fjord and were assumed to be saturating for bacterial uptake. (Note that cellobiose and alanine tripeptide were also added at $10 \mu \mathrm{M}$ concentrations, in effect giving 2 - and 3 -fold greater amounts of the monosaccharide and amino acid supplements, respectively.)

In the first Kiel Fjord experiment, substrate additions were made immediately after the water had been passed through the $1 \mu \mathrm{m}$ filter. For the second Kiel Fjord experiment, after $1 \mu \mathrm{m}$ Nuclepore filtration, the sample was stored at ambient Fjord temperature $\left(20^{\circ} \mathrm{C}\right)$ in the dark for $3 \mathrm{~d}$ prior to the substrate additions. Thus after preincubation, the initial, ambient levels of organic substrates in the second experiment should have been lower than in the first experiment and the bacteria were probably in a physiologically starved condition (Mårdén et al. 1985).

The flasks were incubated in the dark at ambient water temperatures (approximately $20^{\circ} \mathrm{C}$ ). After 1,6 and $24 \mathrm{~h}$ (and, in addition, $3 \mathrm{~h}$ in the second experiment) subsamples were removed from each flask to estimate bacterial production based on the incorporation of ${ }^{3} \mathrm{H}$-thymidine or ${ }^{3} \mathrm{H}$-leucine. To triplicate $10 \mathrm{ml}$ portions of these subsamples, $2.5 \mu \mathrm{Ci}$ of ${ }^{3} \mathrm{H}$-thymidine (final concentration $5.5 \mathrm{nM}$ ) or $2.5 \mu \mathrm{Ci}$ of ${ }^{3} \mathrm{H}$-leucine and cold leucine (final leucine concentration $104 \mathrm{nM}$ ) were added. After $1 \mathrm{~h}$ incubation with the radioisotope, the samples were filtered onto $0.2 \mu \mathrm{m}$ Nuclepore membranes, rinsed 10 times with $1 \mathrm{ml}$ ice-cold $5 \%$ trichloroacetic acid (TCA), and the retained radioactivity was determined in a scintillation counter. Samples poisoned with $100 \mu \mathrm{l}$ of $37 \%$ formaldehyde prior to the radioisotope additions served as controls. For estimations of bacterial growth (as cells $\mathrm{ml}^{-1} \mathrm{~d}^{-1}$ ) or bacterial

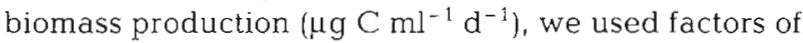
$1.1 \times 10^{18}$ cells $\mathrm{mol}^{-1}$ thymidine (Fuhrman \& Azam 1982) and $3.09 \times 10^{9} \mu \mathrm{g} \mathrm{C} \mathrm{mol}^{-1}$ leucine (Simon \& Azam 1989) respectively.

At the start of the experiments and at each time point, samples were taken from the flasks and fixed with $2 \%$ (final concentration) of $37 \%$ formaldehyde for the determination of bacterial numbers and cell volumes by acridine orange staining and epifluorescence microscopy (Zimmermann \& Meyer-Reil 1974, Hobbie et al. 1977). A factor of $0.2 \mathrm{pg} \mathrm{C} \mu \mathrm{m}^{-3}$ was used to convert bacterial volume to cell carbon (Bratbak 1985).

Lake Kinneret. Two experiments, generally similar in design to those described above, were made with samples taken from meso-eutrophic Lake Kinneret (see Serruya 1978 for a general description of the lake environment) on 17 November 1991 (KIN-1), and 1 January (KIN-2) 1992. Water was taken from $1 \mathrm{~m}$ depth at a central lake station and filtered through $0.8 \mu \mathrm{m}$ Nuclepore filters. One portion of the sample was used immediately (see below) while another subsample was stored at near ambient lake temperatures (21 and $18^{\circ} \mathrm{C}$ for KIN-1 and KIN-2 respectively) in the dark for $4 \mathrm{~d}$ in order to obtain 'starved' bacterial populations. In the Kinneret experiments, only glucose, glutamic acid or a combination of both these substrates at $10 \mu \mathrm{M}$ final concentration was added to the lake waters. Bacterial counts (in this case using the DAPI technique; Porter \& Feig 1980), but no detailed bacterial cell volume determinations, were made and only ${ }^{3} \mathrm{H}$-thymidine was used as a tracer for bacterial productivity measurements. Determination of thymidine uptake was made as previously described but, for the 
measurement of incorporated radioactivity, the filters in this series were processed using the method of Wicks \& Robarts (1987). This technique, which involves washing the TCA precipitate collected on $0.2 \mu \mathrm{m}$ Millipore filters with ethanol-chloroform, gives a more reliable measure of ${ }^{3} \mathrm{H}$-thymidine actually incorporated into bacterial DNA. For Lake Kinneret bacteria, a much higher thymidine conversion factor $\left(10^{19}\right.$ cells $\mathrm{mol}^{-1}$ thymidine) has been empirically determined (Berman unpubl.) and this was used to estimate bacterial production.

For the Kinneret experiments, subsamples were taken at 1, 3 and $24 \mathrm{~h}$ after the addition of substrates.

\section{RESULTS}

\section{Effects of organic substrate additions on bacterial numbers and cell volumes}

The preincubation treatment may have changed bacterial populations in the Kiel Fjord experiments. Initial cell numbers and volumes in the 'starved' sample were lower: $1.43 \times 10^{6}$ cells $\mathrm{ml}^{-1}$ and $0.088 \mu \mathrm{m}^{3}$ cell ${ }^{-1}$, compared to $3.12 \times 10^{6}$ cells $\mathrm{ml}^{-1}$ and $0.12 \mu \mathrm{m}^{3}$ cell $^{-1}$ in the first experiment with freshly sampled water (Table 1).

The time courses of change in bacterial numbers, biovolumes and carbon concentration over $24 \mathrm{~h}$ in the Kiel experiments are shown in Fig. 1a to c, and a summary of the changes in these parameters relative to their values $1 \mathrm{~h}$ after substrate addition is given in Table 2. In the fresh samples, no obvious change in bacterial numbers was observed after $6 \mathrm{~h}$ but by $24 \mathrm{~h}$ all samples, including the unsupplemented control, had increased by between 1.6-and 3.3-fold, with the greatest stimulus given by glucose addition (Fig. 1a). In contrast, in the preincubated sample, there was essentially no rise in cell numbers even after $24 \mathrm{~h}$ with the exception of a 3 -fold increase with added glucose (Fig, 1a).

Bacterial cell volumes changed relatively iittle (maximum 1.4-fold increase) over $24 \mathrm{~h}$ in supplemented treatments of the fresh sample, and they even decreased slightly in the control (Fig. 1b). However, by $24 \mathrm{~h}$, cell volumes increased perceptibly in the preincubated series with added substrates, especially with cellobiose and glucose (3.0- and 2.8-fold respectively), but not in the unsupplemented control (Fig. 1b).

The impact of added organic substrate was greatest when bacterial cell counts were multiplied by measured cell volumes to estimate changes in concentrations of bacterial carbon (Fig. 1c). In this case, glucose addition had the greatest effect (8.4- and 4.6-fold increase relative to unsupplemented controls for preincubated and fresh cells respectively). Cellobiose was the next most effective substrate in the preincubated sample (4.3-fold increase after $24 \mathrm{~h}$ ). Unsupplemented controls in these experiments showed a $50 \%$ increase in fresh, and a $12 \%$ decrease in preincubated, samples in terms of bacterial carbon over $24 \mathrm{~h}$.

The oligomers cellobiose and alanine tripeptide generally did not have a greater enhancing effect on bacterial numbers or volumes than did their analogous monomers. Stimulation by oligomers was most evident in the increased bacterial cell volume after $24 \mathrm{~h}$ in the Kiel Fjord preincubated sample (cellobiose only), and for both oligomers after $48 \mathrm{~h}$ in the Kiel Fjord fresh sample (results not shown). This was also reflected by enhanced incorporation of both radioactive tracers in the respective experiments (see below), but not by increases in cell numbers.

Bacterial growth responses to organic supplements were different in the 2 Kinneret experiments. Here, the effect of the $4 \mathrm{~d}$, dark preincubation treatment on initial bacterial numbers was not consistent; in KIN-1 this treatment caused a $42 \%$ decrease in initial cell numbers compared to the fresh sample, whereas in KIN-2 a

Table 1. Initial bacterial numbers, cell volumes or morphology, specific daily growth rates and substrate giving greatest growth response

\begin{tabular}{|c|c|c|c|c|c|}
\hline & & $\begin{array}{l}\text { No. of cells } \\
\left(\times 10^{6} \mathrm{ml}^{-1}\right)\end{array}$ & $\begin{array}{l}\text { Cell volume }\left(\mu \mathrm{m}^{3}\right) \\
\text { or shape }\end{array}$ & $\begin{array}{l}\text { Doubling time } \\
\text { (d) }\end{array}$ & $\begin{array}{l}\text { Max. response } \\
\text { substrate }^{b}\end{array}$ \\
\hline Kiel Bight & $\begin{array}{l}\text { Fresh } \\
\text { Preincubated }\end{array}$ & $\begin{array}{l}3.12 \\
1.43\end{array}$ & $\begin{array}{l}0.120 \\
0.088\end{array}$ & $\begin{array}{c}1.3 \\
-\end{array}$ & $\begin{array}{l}\text { Glucose } \\
\text { Glucose }\end{array}$ \\
\hline KIN-1 & $\begin{array}{l}\text { Fresh } \\
\text { Preincubated }\end{array}$ & $\begin{array}{l}2.50 \\
1.44\end{array}$ & $\begin{array}{l}\text { Small cocci } \\
\text { Small cocci }\end{array}$ & $\begin{array}{l}1.9 \\
0.9\end{array}$ & $\begin{array}{l}\text { None } \\
\text { Glucose }\end{array}$ \\
\hline KIN-2 & $\begin{array}{l}\text { Fresh } \\
\text { Preincubated }\end{array}$ & $\begin{array}{l}3.10 \\
4.70\end{array}$ & $\begin{array}{l}\text { Small cocci } \\
\text { Small cocci }\end{array}$ & $\begin{array}{r}2.0 \\
32.9\end{array}$ & $\begin{array}{c}\text { Glutamic } \\
\text { Glutamic + glucose }\end{array}$ \\
\hline
\end{tabular}


Fresh Sample
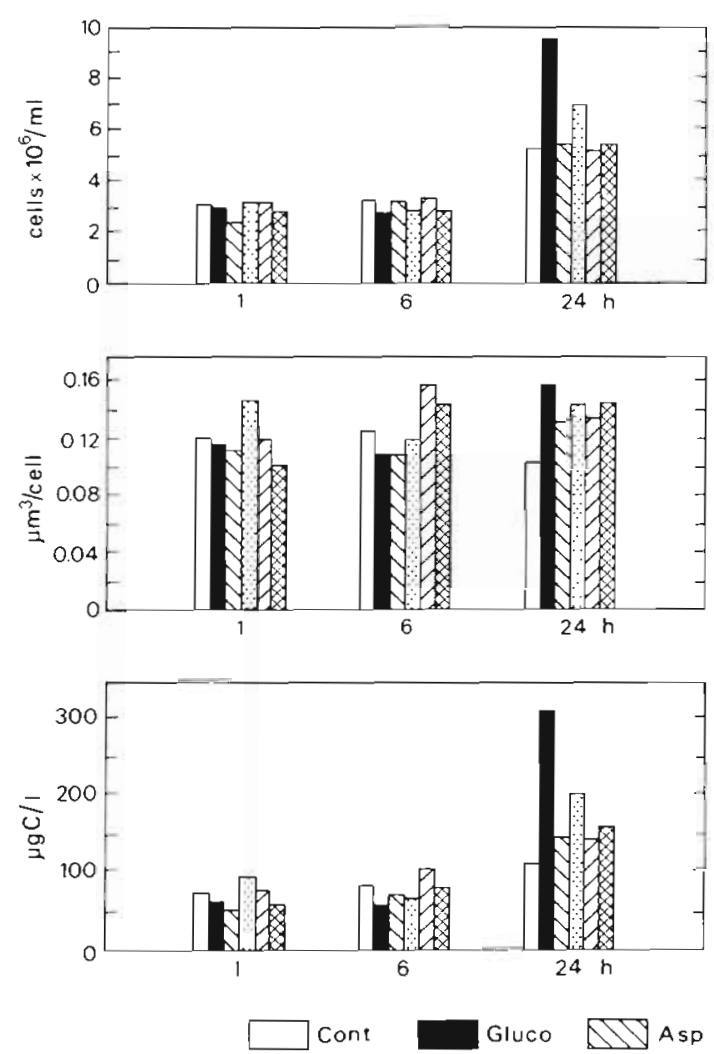

Preincubated Sample
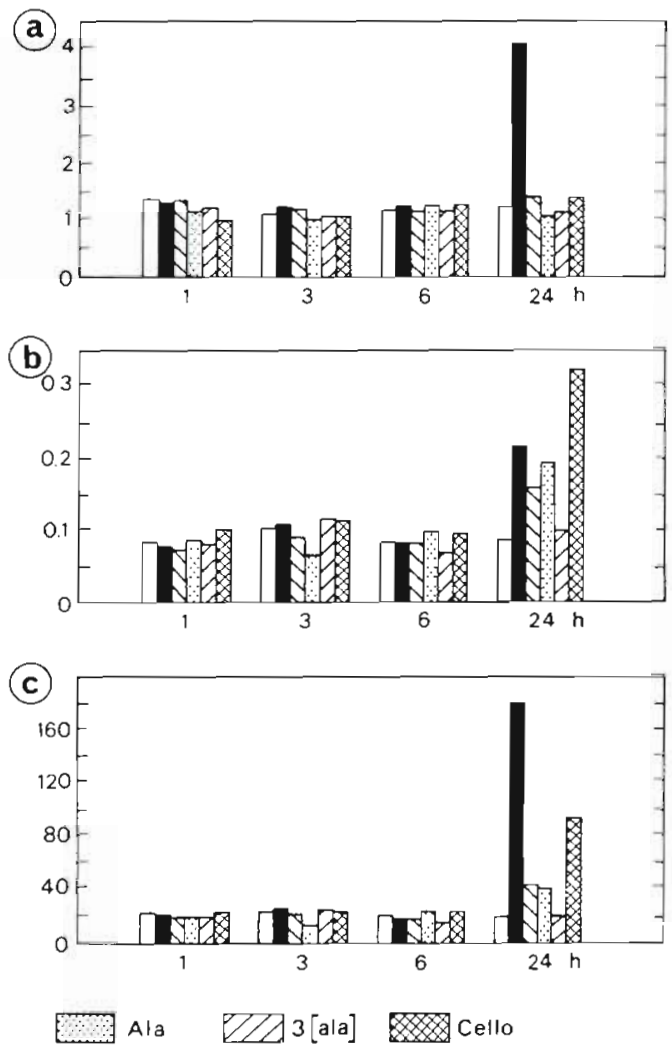

Fig. 1 Kiel Fjord experiments. Left side: fresh sample, 8 September 1991; right side: preincubated sample, 20 September 1991 (a) Bacterial cell numbers, (b) bacterial mean cell volume, (c) bacterial carbon. Cont = control, Gluco = glucose, Asp = aspartic acid, Ala = alanine, 3[ala $]=$ alanine tripeptide, Cello $=$ cellobiose

Table 2. Effect of substrate additions on bacterial numbers, volumes and carbon biomass. Results given as the ratio of cell counts, volumes or bacterial carbon measured at $24 \mathrm{~h}$ and at $1 \mathrm{~h}$ after substrate addition

\begin{tabular}{|c|c|c|c|c|c|c|}
\hline & Control & Glucose & Aspartic & c Alanine & Ala-3 & Cellobiose \\
\hline \multicolumn{7}{|l|}{ Kiel, cell counts } \\
\hline Fresh & 1.7 & 3.3 & 2.2 & 2.2 & 1.6 & 1.9 \\
\hline Preincubated & 0.9 & 3.0 & 1.1 & 0.9 & 1.0 & 1.4 \\
\hline \multicolumn{7}{|c|}{ Kiel, cell volumes } \\
\hline Fresh & 0.9 & 1.4 & 1.2 & 1.0 & 1.1 & 1.4 \\
\hline Preincubated & 1.0 & 2.8 & 2.2 & 2.3 & 1.7 & 3.0 \\
\hline \multicolumn{7}{|c|}{ Kiel, carbon biomass } \\
\hline Fresh & 1.5 & 4.6 & 2.6 & 2.2 & 2.0 & 2.7 \\
\hline \multirow[t]{2}{*}{ Preincubated } & 0.9 & 8.4 & 2.4 & 2.1 & 1.2 & 4.3 \\
\hline & Control & \multicolumn{2}{|c|}{ Glutamic } & lucose $G$ & \multicolumn{2}{|c|}{ Glutamic + glucose } \\
\hline \multicolumn{7}{|c|}{ KIN-1, cell counts } \\
\hline Fresh & 1.3 & \multirow{2}{*}{$\begin{array}{l}1.3 \\
1.6\end{array}$} & \multicolumn{2}{|r|}{1.0} & \multicolumn{2}{|c|}{1.2} \\
\hline Preincubated & 1.6 & & & 3.1 & 2.4 & 4 \\
\hline \multicolumn{7}{|c|}{ KIN-2, cell counts } \\
\hline Fresh & 1.2 & \multicolumn{2}{|c|}{3.0} & 1.5 & \multicolumn{2}{|c|}{1.3} \\
\hline Preincubated & 1.3 & \multicolumn{2}{|c|}{2.0} & 1.8 & \multicolumn{2}{|c|}{2.5} \\
\hline
\end{tabular}

$52 \%$ increase was observed (Table 1). Over $24 \mathrm{~h}$, the supplemented fresh samples in this series showed no or only slight increases in cell number over that of controls, with the exception of glutamic acid in KIN-2 (Table 2, Fig. 2).

Cell multiplication was more consistently stimulated by organic supplements in preincubated Lake Kinneret water than in fresh samples (Table 2). In the preincubated treatment of KIN-1 the greatest increases in bacterial number were observed with added glucose (3.1fold) and with combined glucose and glutamic acid (2.4-fold). In preincubated KIN-2 the greatest stimulation of bacterial numbers was given by the combined supplement. Curiously, the unsupplemented sample in the preincubated KIN-1 experiment continued to increase in cell number (1.6-fold) over $24 \mathrm{~h}$ (Fig. 2a).

Cell volumes were not quantified in the Kinneret experiments, but qualita- 

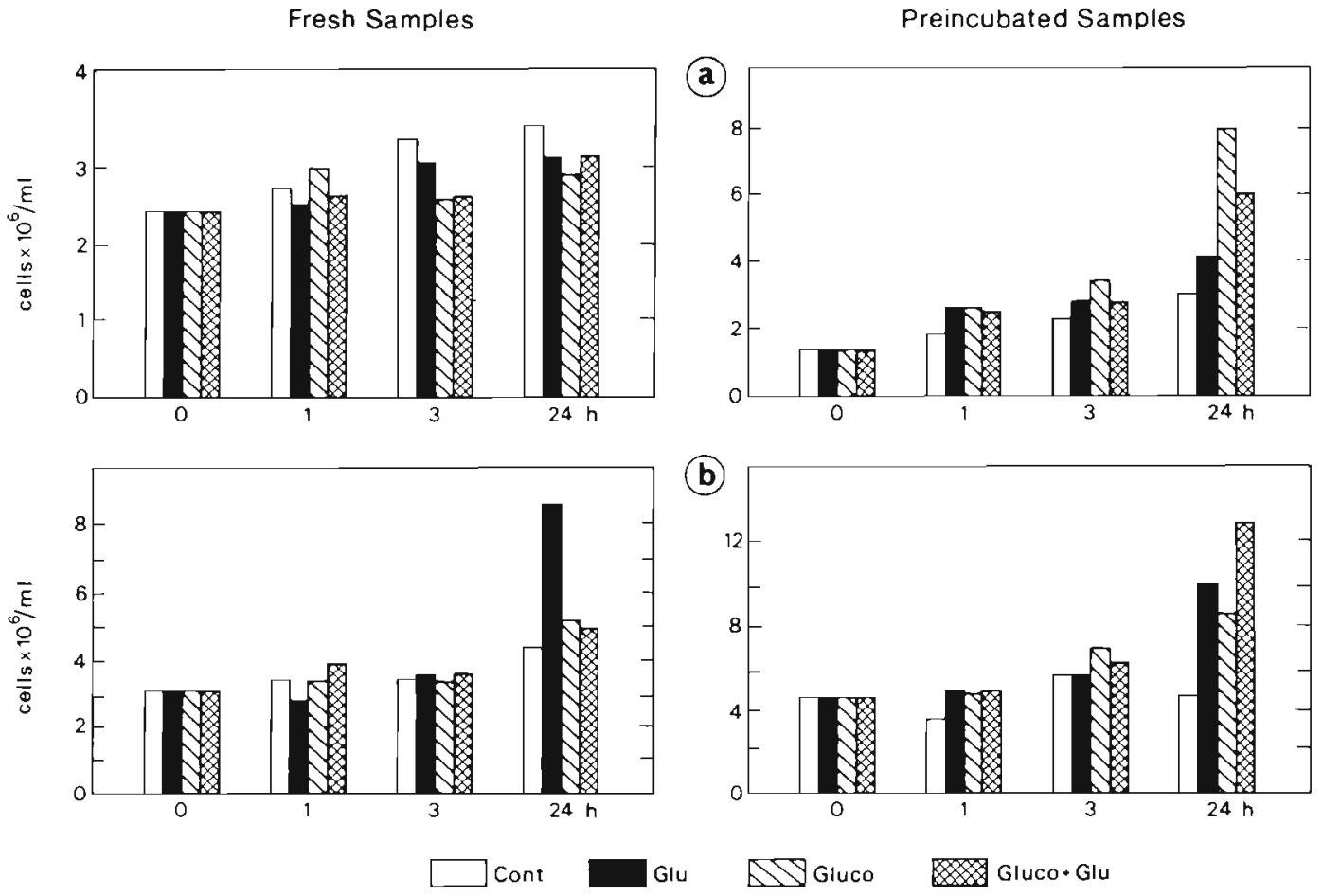

Fig. 2. Lake Kinneret experiments: bacterial cell counts. Left side: fresh samples; right side: preincubated samples. (a) KIN-1, 17 November 1991; (b) KIN-2, 1 January 1992. Cont = control, Glu = glutamic acid, Gluco = glucose, Gluco + Glu $=$ glucose and glutamic acid

tively the population remained predominantly in the form of small cocci for all treatments in the fresh samples. In the preincubated sample of KIN-1 there was a shift from almost $100 \%$ small cocci $(0.4$ to $0.6 \mu \mathrm{m})$ initially to a population which had about $40 \%$ of larger cells $(0.6$ to $0.8 \mu \mathrm{m})$ in all the supplemented treatments, but not in the control flasks after $24 \mathrm{~h}$. Similarly, in KIN-2, mixed populations of cocci and rodshaped cells developed in all the supplemented, preincubated samples.

The above results reflect changes in bacterial numbers after a relatively long time period ( $24 \mathrm{~h}$ incubation). Over shorter time intervals, no clear response in cell numbers or volumes was observed after $6 \mathrm{~h}$ in the Kiel experiments, and only slight increases in cell numbers in supplemented samples relative to the controls were found in preincubated Kinneret samples after 3 h (Fig. 2).

\section{${ }^{3} \mathrm{H}$-thymidine and ${ }^{3} \mathrm{H}$-leucine incorporation}

In Figs. $3 \& 4$ we show the patterns of ${ }^{3} \mathrm{H}$-thymidine and ${ }^{3} \mathrm{H}$-leucine incorporation in the Kiel Fjord and Kinneret experiments, respectively, and, in Table 3, we give the relative rates of radiotracer incorporation expressed as the ratio of dpm measured after $24 \mathrm{~h}$ to dpm measured after $1 \mathrm{~h}$ (taken as the incorporation rate of the initial bacterial populations).

In the Kiel experiments, after 1,3 and $6 \mathrm{~h}$, the amount of radioisotope incorporated by the bacteria in samples with added substrates was similar to that in unsupplemented controls, with the exception of the strong depression of ${ }^{3} \mathrm{H}$-leucine, and, to a lesser extent, ${ }^{3} \mathrm{H}$-thymidine uptake observed with the addition of alanine. After $24 \mathrm{~h}$, however, all flasks supplemented with organic substrates showed increased rates of ${ }^{3} \mathrm{H}$ thymidine incorporation, especially in the preincubated samples with added cellobiose and glucose (21.5-fold and 8.1-fold; Table 3). The incorporation rates for ${ }^{3} \mathrm{H}$-leucine were enhanced to an even greater extent by the organic supplements but, in this case, the maximum stimulation after $24 \mathrm{~h}$ was observed with alanine addition, with a somewhat lower response for the aspartic acid, glucose and cellobiose addition treatments (Fig. 3). Note, however, that at $1 \mathrm{~h}$ the addition of alanine had depressed the incorporation rate of ${ }^{3} \mathrm{H}$ leucine by approximately 4 -fold (Fig. 3), thus markedly increasing the ratio of ${ }^{3} \mathrm{H}$-leucine incorporated at $24 \mathrm{~h}$ relative to that incorporated after $1 \mathrm{~h}$ (Table 3 ). Although alanine addition had a pronounced effect in the preincubated Kiel experiment, alanine tripeptide gave the least stimulation of ${ }^{3} \mathrm{H}$-leucine incorporation over $24 \mathrm{~h}$. 
Fresh Sample
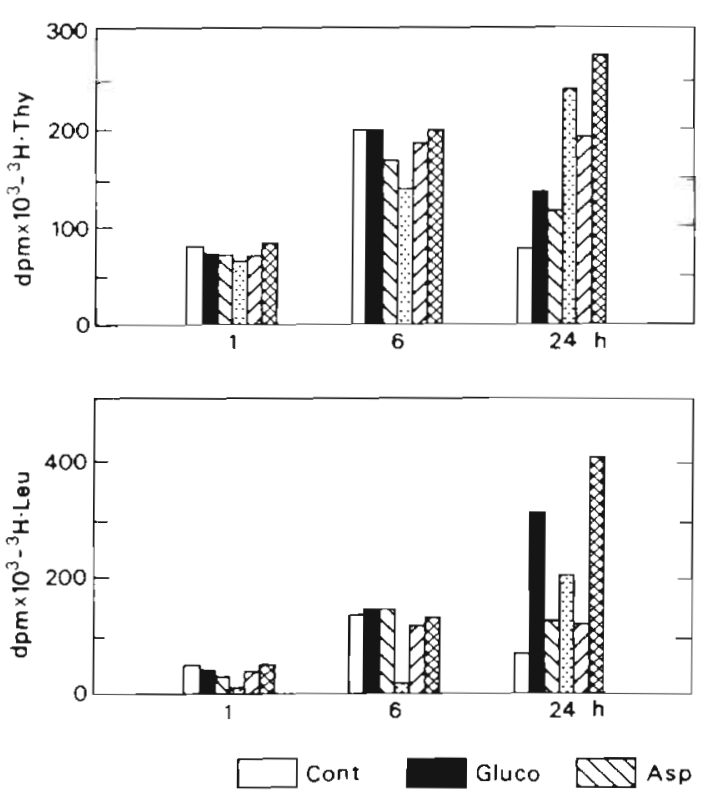

Preincubated Sample

(a)

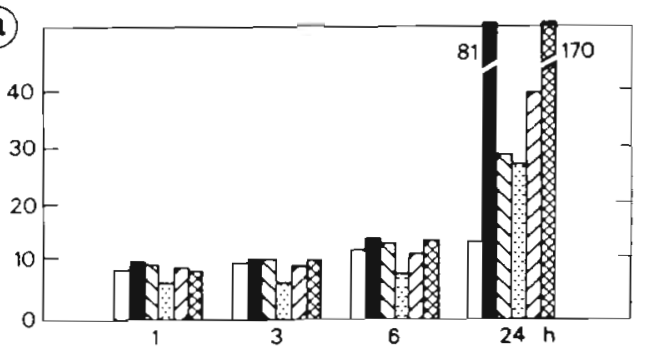

(b)

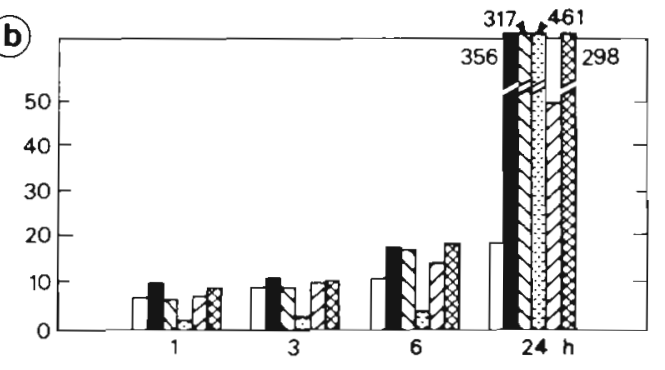

Ala

Fig. 3. Kiel Fjord experiments. Left side: fresh sample; right side: preincubated sample. (a) ${ }^{3} \mathrm{H}$-thymidine incorporation, (b) ${ }^{3} \mathrm{H}$-leucine incorporation. Substrate abbreviations as in Fig. 1

Fresh samples
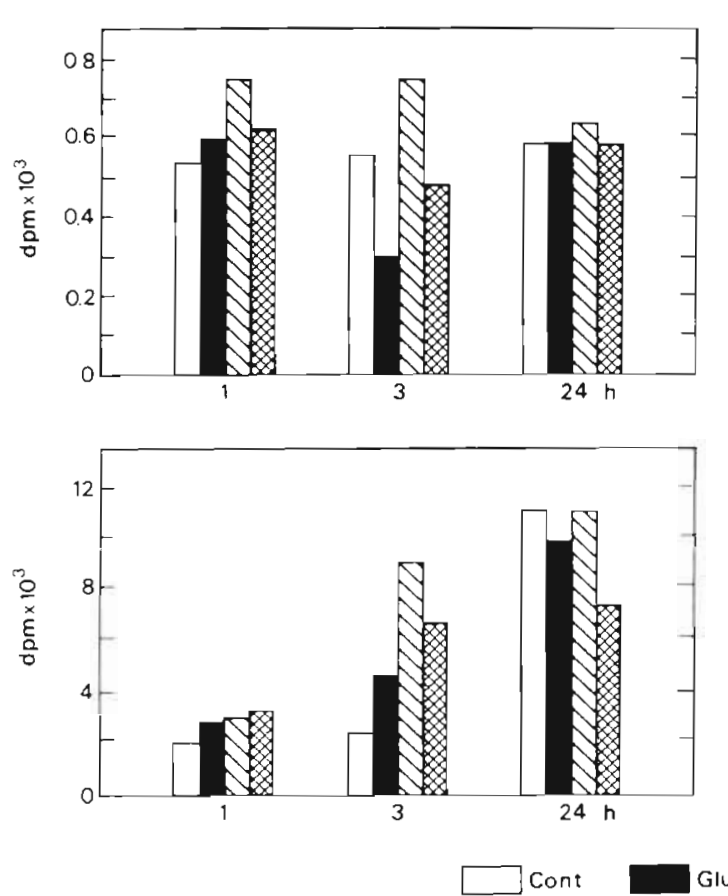

Preincubated samples

(a)

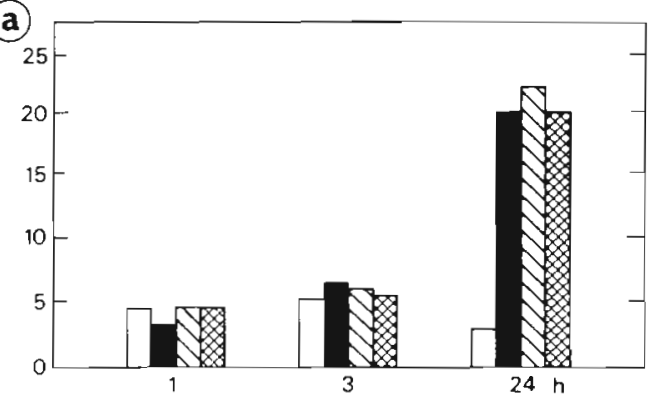

(b)

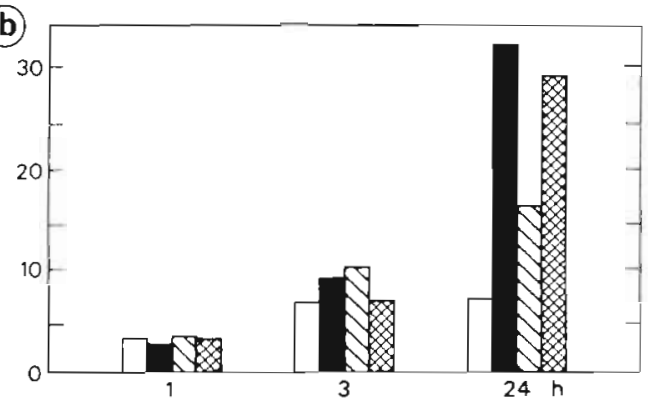

Gluco+Glu

Fig. 4. Lake Kinneret experiments: ${ }^{3} \mathrm{H}$-thymidine incorporation. Left side: fresh samples; right side: preincubated samples (a) KIN-1, 17 November 1991; (b) KIN-2, 1 January 1992. Substrate abbreviations as in Fig. 2 
In the Kinneret experiments (Fig. 4, Table 3), the greatest stimulation of ${ }^{3} \mathrm{H}$-thymidine incorporation by added organic substrates relative to the unsupplemented controls was also observed in preincubated samples. In KIN-2, radioisotope incorporation rates after $24 \mathrm{~h}$ increased markedly in the controls, especially in the fresh sample (Table 3 ).

The general pattern of response to added substrates in fresh and preincubated samples was similar in terms of cell numbers and radiotracer uptake within each experiment. However, substrates which gave the greatest response in terms of thymidine or leucine incorporation were not always identical to those which gave the greatest cell yield (e.g. in the Kiel Fjord preincubated sample, maximum ${ }^{3} \mathrm{H}$-thymidine uptake and cell number increase were stimulated by cellobiose and glucose, respectively).

\section{Comparison of thymidine to leucine uptake}

The most obvious difference between the 2 radiotracers used in the Kiel experiments $\left({ }^{3} \mathrm{H}\right.$-thymidine, ${ }^{3} \mathrm{H}$-leucine) was the strong inhibition of ${ }^{3} \mathrm{H}$-leucine incorporation which was observed with the addition of alanine after 1,3 and $6 \mathrm{~h}$ (Fig. 3a, b). Surprisingly though, the rate of ${ }^{3} \mathrm{H}$-leucine incorporation in the presence of alanine recovered strongly by $24 \mathrm{~h}$ (27-fold in fresh Kiel Fjord water and 255-fold in preincubated Fjord water). These effects were not observed with alanine tripeptide additions.

In general, at 1,3 and $6 \mathrm{~h}$ after the start of the Kiel water incubations, rather constant thymidine to leucine uptake ratios (expressed as dpm incorporated

Table 3. Relative thymidine and leucine uptake rates. Results given as the ratio of dpm at $24 \mathrm{~h}$ to dpm at $1 \mathrm{~h}$ after substrate addition

\begin{tabular}{|c|c|c|c|c|c|c|}
\hline & Control & Glucose & Aspartic & Alanine & Ala-3 & Cellobiose \\
\hline \multicolumn{7}{|l|}{ Kiel thymidine } \\
\hline Fresh & 1.0 & 1.8 & 1.6 & 3.7 & 2.7 & 3.3 \\
\hline Preincubated & 1.5 & 8.1 & 3.0 & 4.3 & 4.3 & 21.5 \\
\hline \multicolumn{7}{|l|}{ Kiel, leucine } \\
\hline Fresh & 1.4 & 9.8 & 5.1 & 27.4 & 3.4 & 7.9 \\
\hline \multirow[t]{2}{*}{ Preincubated } & 2.6 & 36.1 & 41.9 & 254.6 & 7.0 & 34.1 \\
\hline & \multicolumn{2}{|c|}{ Control } & Glutamic & Glucose & \multicolumn{2}{|c|}{ Glutamic + glucose } \\
\hline \multicolumn{7}{|c|}{ KIN-1, thymidine } \\
\hline Fresh & \multicolumn{2}{|c|}{1.1} & 1.0 & 0.9 & \multicolumn{2}{|r|}{0.9} \\
\hline Preincubated & \multicolumn{2}{|c|}{0.7} & 5.8 & 5.0 & \multicolumn{2}{|r|}{4.4} \\
\hline \multicolumn{7}{|c|}{ KIN-2, thymidine } \\
\hline Fresh & \multicolumn{2}{|c|}{3.9} & 3.6 & 3.6 & \multicolumn{2}{|r|}{2.2} \\
\hline Preincubated & \multicolumn{2}{|c|}{2.1} & 10.4 & 4.7 & \multicolumn{2}{|r|}{8.4} \\
\hline
\end{tabular}

of each radiotracer) were found for the controls and all treatments, with the exception of the alanine addition. The ratios for fresh samples were about twice those of the preincubated samples (average $=1.74 \pm 0.55$ in fresh and $0.99 \pm 0.19$ in preincubated samples). After $24 \mathrm{~h}$, large changes in this ratio occurred, especially in many of the supplemented samples. The increases observed for the incorporation rate of ${ }^{3} \mathrm{H}$-leucine in samples after $24 \mathrm{~h}$ compared to those at $1 \mathrm{~h}$ were all greater than those noted for ${ }^{3} \mathrm{H}$-thymidine (Table 3 , Fig. 3) and thus the ratio of $\mathrm{dpm}{ }^{3} \mathrm{H}$-thymidine incorporated to $\mathrm{dpm}{ }^{3} \mathrm{H}$-leucine incorporated dropped considerably at $24 \mathrm{~h}$.

\section{${ }^{3} \mathrm{H}$-thymidine and ${ }^{3} \mathrm{H}$-leucine incorporation as predictors of bacterial productivity}

We calculated bacterial growth rates (as cells per ml per $24 \mathrm{~h}$ ) using the measured values of ${ }^{3} \mathrm{H}$-thymidine or ${ }^{3} \mathrm{H}$-leucine incorporation and cell number conversion factors for these radiotracers (see 'Methods'). In ecological investigations, such estimates of growth rates are often used to obtain integrated daily bacterial production. In order to test the validity of extrapolating ${ }^{3} \mathrm{H}$-thymidine or ${ }^{3} \mathrm{H}$-leucine incorporation measurements made after $1 \mathrm{~h}$ incubations with or without substrate addition, we calculated the 'predicted' bacterial production for the $24 \mathrm{~h}$ incubation period on the basis of the initial (after $1 \mathrm{~h}$ ) ${ }^{3} \mathrm{H}$-thymidine or ${ }^{3} \mathrm{H}$-leucine incorporation rates. The resulting 'predicted production' values were compared to 'observed' production values, which were derived from direct microscopical counts of bacteria after $1 \mathrm{~h}$ and after $24 \mathrm{~h}$ of incubation (Table 4).

For unsupplemented samples of Kiel (fresh) and Kinneret water, the ratio of observed to predicted production ranged from 0.53 to 1.51 for ${ }^{3} \mathrm{H}$-thymidine. $\mathrm{Ob}$ served production based on cell counts was negative in the control and in 2 of the supplemented, preincubated Kiel samples, and in 1 Kinneret sample. Although the predictive ability of the thymidine uptake method was, with one exception, reasonable for the unsupplemented samples (no more than $\pm 50 \%$ of directly observed cell counts), it was generally much poorer in flasks to which organic substrates had been added, especially those with preincubated water. Only limited data based on ${ }^{3} \mathrm{H}$-leucine uptake were obtained, but here too the ratio of observed to predicted production was either much greater or much lower than 1 in most of the supplemented samples. 
Table 4. Observed and predicted bacterial production in unsupplemented controls and supplemented samples. Production values $\left(\mathrm{N}_{24}\right)$ given as cells $\times 10^{6} \mathrm{ml}^{-1}$. $\mathrm{N}_{24}$ obs. $=$ (bacterial counts at $\left.24 \mathrm{~h}\right)$ - (bacterial counts at $\left.1 \mathrm{~h}\right)_{i} \mathrm{~N}_{24}$ pred. $=$ expected cell numbers at $24 \mathrm{~h}$ calculated from radiotracer uptake at $1 \mathrm{~h}_{;} \mathrm{R}_{\mathrm{T}}$ and $\mathrm{R}_{\mathrm{L}}=$ ratio of observed production to predicted production (at $24 \mathrm{~h}$ ) based on ${ }^{3} \mathrm{H}$-thymidine or ${ }^{3} \mathrm{H}$-leucine incorporation, respectively

\begin{tabular}{|c|c|c|c|c|c|c|}
\hline Sample & & $\mathrm{N}_{24}$ obs. & $\begin{array}{c}\mathrm{N}_{24} \text { pred., } \\
{ }^{3} \mathrm{H} \text {-thymidine }\end{array}$ & $\mathrm{R}_{\mathrm{T}}$ & $\begin{array}{l}\mathrm{N}_{24} \text { pred., } \\
{ }^{3} \mathrm{H} \text {-leucine }\end{array}$ & $\mathrm{R}_{\mathrm{L}}$ \\
\hline Kiel, fresh & $\begin{array}{l}\text { Control } \\
\text { Glucose } \\
\text { Aspartic } \\
\text { Alanine } \\
\text { Ala-3 } \\
\text { Cellobiose }\end{array}$ & $\begin{array}{l}2.24 \\
6.68 \\
2.98 \\
3.85 \\
2.00 \\
2.50\end{array}$ & $\begin{array}{l}2.98 \\
2.76 \\
2.97 \\
2.30 \\
2.56 \\
3.24\end{array}$ & $\begin{array}{l}0.75 \\
2.42 \\
1.00 \\
1.68 \\
0.78 \\
0.77\end{array}$ & $\begin{array}{l}4.62 \\
2.74 \\
2.12 \\
0.39 \\
2.99 \\
6.70\end{array}$ & $\begin{array}{l}0.48 \\
2.44 \\
1.41 \\
9.84 \\
0.67 \\
0.37\end{array}$ \\
\hline Kiel, preincubated & $\begin{array}{l}\text { Control } \\
\text { Glucose } \\
\text { Aspartic } \\
\text { Alanine } \\
\text { Ala-3 } \\
\text { Cellobiose }\end{array}$ & $\begin{array}{r}-0.16 \\
2.78 \\
0.10 \\
-0.09 \\
-0.06 \\
0.44\end{array}$ & $\begin{array}{l}0.25 \\
0.29 \\
0.28 \\
0.18 \\
0.27 \\
0.24\end{array}$ & $\begin{array}{r}-0.64 \\
9.51 \\
0.36 \\
-0.50 \\
-0.22 \\
1.82\end{array}$ & $\begin{array}{l}0.71 \\
1.19 \\
0.94 \\
0.16 \\
0.77 \\
0.74\end{array}$ & $\begin{array}{r}-0.23 \\
2.33 \\
0.11 \\
-0.58 \\
-0.08 \\
0.59\end{array}$ \\
\hline KIN-1, fresh & $\begin{array}{l}\text { Control } \\
\text { Glutamic } \\
\text { Glucose } \\
\text { Glutamic + glucose }\end{array}$ & $\begin{array}{r}0.83 \\
0.58 \\
-0.11 \\
0.52\end{array}$ & $\begin{array}{l}1.58 \\
1.88 \\
2.39 \\
0.94\end{array}$ & $\begin{array}{r}0.53 \\
0.31 \\
-0.05 \\
0.27\end{array}$ & & \\
\hline KIN-1, preincubated & $\begin{array}{l}\text { Control } \\
\text { Glutamic } \\
\text { Glucose } \\
\text { Glutamic + glucose }\end{array}$ & $\begin{array}{l}1.15 \\
1.61 \\
5.50 \\
3.56\end{array}$ & $\begin{array}{l}1.45 \\
0.97 \\
1.31 \\
1.38\end{array}$ & $\begin{array}{l}0.79 \\
1.65 \\
4.21 \\
2.58\end{array}$ & & \\
\hline KIN-2, fresh & $\begin{array}{l}\text { Control } \\
\text { Glutamic } \\
\text { Glucose } \\
\text { Glutamic + glucose }\end{array}$ & $\begin{array}{l}0.80 \\
5.80 \\
1.80 \\
1.00\end{array}$ & $\begin{array}{l}0.53 \\
0.73 \\
1.22 \\
0.88\end{array}$ & $\begin{array}{l}1.51 \\
7.95 \\
1.47 \\
1.14\end{array}$ & & \\
\hline KIN-2, preincubated & $\begin{array}{l}\text { Control } \\
\text { Glutamic } \\
\text { Glucose } \\
\text { Glutamic + glucose }\end{array}$ & $\begin{array}{l}1.10 \\
5.00 \\
3.70 \\
7.90\end{array}$ & $\begin{array}{l}0.94 \\
0.85 \\
2.10 \\
0.91\end{array}$ & $\begin{array}{l}1.17 \\
5.86 \\
1.76 \\
8.69\end{array}$ & & \\
\hline
\end{tabular}

\section{DISCUSSION}

\section{Response in cell numbers and biovolumes as indicators of in situ substrate limitation}

There are only a few studies described in the literature with an experimental design comparable to ours. Güde (1986) supplemented sterile, filtered Lake Constance water with $1 \mathrm{mg} \mathrm{l^{-1 }}$ yeast extract and $1 \mu \mathrm{m}$ filtered lake water and observed a very strong increase in bacterial numbers during the first 2 to $3 \mathrm{~d}$ under these conditions. Similar results were obtained by Münster \& Chróst (1990), who incubated dissolved organic matter released by algae with natural bacterial populations over a $24 \mathrm{~h}$ period. However, the substrates used by these investigators were more varied in terms of molecular composition, i.e. not single compounds as in the present study. Short term (2 d) investigations were also carried out by Chin-Leo \& Kirchman (1990) who grew seawater cultures from a $<1.0 \mu \mathrm{m}$ size fraction of Chesapeake Bay (USA) and
Mid-Atlantic Bight water without substrate additions. In both locations, bacterial numbers rose steadily from the beginning of the experiment, with a more pronounced increase in Chesapeake Bay water than in Atlantic water. A somewhat similar approach to ours was also taken by Toolan et al. (1991) who showed that bacteria in Calder Lake (New York. USA) responded to added orthophosphate by increased ${ }^{3} \mathrm{H}$-thymidine incorporation and cell numbers (usually measured after $96 \mathrm{~h}$ ). These results were interpreted as indicating that dissolved inorganic phosphorus was limiting bacterial growth in the lake. In our experiments we focussed on the effects of organic substrate limitation. The concentrations of inorganic $N$ or $P$ nutrients were not determined in these samples. However, in neither Kiel nor Kinneret waters would we expect limitation by $N$ and $P$ on the sampling dates. In the Kiel Fjord, dissolved inorganic nitrogen (DIN) and soluble reactive phosphorus (SRP) levels are about 4.6 and $1.5 \mu \mathrm{M}$, respectively, in September. In Lake Kinneret in mid-November epilimnic 
concentrations of DIN and SRP are rather low, 1.5 and $0.1 \mu \mathrm{M}$ respectively; in January, after lake overturn, these levels would be much higher, $>25$ and $0.2 \mu \mathrm{M}$ respectively.

In our experiments, 'natural' bacterial populations from Kiel Fjord and Lake Kinneret water were prepared by gentle filtration through $1.0 \mu \mathrm{m}$ and $0.8 \mu \mathrm{m}$ Nuclepore filters, respectively. Although visual microscopic inspection failed to reveal any significant numbers of flagellates or other bacterivorous protozoa, we are aware that some of these organisms, as well as bacteriophages, may have been present and could have interfered with the experiments. Nevertheless, in no instance did we record a profound decrease in bacterial numbers over $24 \mathrm{~h}$ as might have been expected if bacterivorous protozoans or phages had been very active.

The varied responses to organic substrate additions which we observed were undoubtedly due to the different initial physiological states and the recent nutrient histories of the natural bacterial populations. Samples both from the Kiel Fjord and Lake Kinneret (KIN-2) were taken at seasons when ambient nutrient and organic substrate concentrations were anticipated to be high, i.e. under conditions when the bacteria should have been nutrient replete. In the case of KIN-1, taken in November when the lake was still strongly stratified and when phytoplankton concentrations were low, there could have been reduced availability of substrates for bacterial growth. We expected that the bacteria which were preincubated for several days would be more substrate depleted than those in freshly sampled water, although it is unlikely that these preinucubated samples had reached conditions of extreme stress and 'non-growth' (Kjelleberg et al. 1987). A reduction in cell size, which is typical for the initial starvation process (Kjelleberg \& Hermansson 1984), can be assumed to have occurred in the preincubated Kiel sample.

The most obvious responses of bacteria to organic substrate addition should be changes in cell numbers and/or volume, but rapid changes in these parameters would only be expected if the ambient levels of substrate required for growth were inadequate or limiting. Morita (1986) observed that bacterial multiplication upon the addition of nutrients after starvation required a lag phase, the length of which was dependent on the duration of the starvation period. Thus the time necessary for bacterial response might be on the order of many hours. In contrast, Azam \& Cho (1987) found that marine bacteria could display very high substrate uptake activity for brief periods (seconds or minutes), presumably as a means of taking advantage of episodic inputs of dissolved organic compounds. The delay which we observed in expression of cell growth or multiplication may have been due to the time needed for enzyme induction or derepression (Chróst et al. 1989, Chróst 1991), or because of the time required by hydrolytic, extracellular enzymes to generate monomers in the cases where oligomers were supplied (Hoppe 1983). This observation is consistent with the suggestion of Gocke et al. (1987) that shortterm fluctuations of microbial numbers and activities in coastal Baltic water are not caused by metabolic responses of bacteria to rapid variations in substrate concentration, but rather may be attributed to variations of hydrographic conditions which bring about different bacterial populations.

In a situation with adequate concentration of natural substrate, bacterial populations would be expected to increase even in unsupplemented samples, especially upon the removal of bacterivorous grazers. This appeared to be the case in the freshly sampled Kiel water in which there was an increase of cell numbers at $24 \mathrm{~h}$ in the unsupplemented control, indicating that, initially, there was no strong substrate limitation for bacterial growth in these waters.

In the case of the preincubated Kiel experiment, no change in bacterial counts or volume was observed over $24 \mathrm{~h}$ in the unsupplemented control, presumably because, during the storage period, the bacteria had exhausted the substrates which were initially present. Interestingly, the main response to substrate enrichment in the preincubated Kiel sample was an increase of about 2 -fold in bacterial volumes, rather than an increase in cell numbers. This result emphasizes the limitations of regarding changes in cell number as a sole criterion for bacterial growth.

An increase in cell size prior to cell division would normally be an expected growth sequence when starved cells encounter utilizable organic substrates and, indeed, we observed that preincubated bacteria grew to the size of those in freshly taken samples, or even larger, when substrates were added. Stimulation of bacterial numbers and cell volumes by organic substrate additions relative to the controls in the Kiel experiments was usually greater in preincubated than in fresh samples (Table 2).

The impact of preincubation in the Kinneret experiments was less clear-cut. Unsupplemented controls in KIN-2 showed similar growth responses to those observed for Kiel waters, but in the preincubated unsupplemented sample of KIN-1, bacterial numbers continued to increase over $24 \mathrm{~h}$. However, as noted above, the morphological types of bacteria which grew in the supplemented, preincubated Kinneret samples appeared to be different from those which developed in the fresh samples.

On the assumption that bacterivorous grazers were mostly eliminated by prefiltration through $1 \mu \mathrm{m}$ Nucle- 
pore filters, the changes in bacterial numbers in unsupplemented controls are indicative of the potential growth rates of the indigenous bacterial populations initially present in the water samples. From the data shown in Table 1 it can be seen that the generation times in the controls of fresh samples from Kiel water and from Lake Kinneret ranged from about 1 to $2 \mathrm{~d}$. These are somewhat slower than the daily doubling sometimes used as a typical bacterial growth rate for aquatic environments (Pace 1988) but nevertheless are close to the growth rates reported by others (see Table 1 in Pace 1988). These data, together with the continued growth of bacteria in unsupplemented fresh samples and the only moderate response of bacterial growth to the addition of organic supplements to fresh samples, indicate that the initial bacterial populations in both the Kiel and Kinneret series were not extremely limited with respect to ambient substrate supply.

\section{${ }^{3} \mathrm{H}$-thymidine and ${ }^{3} \mathrm{H}$-leucine as tracers for in situ substrate limitation}

In this work, we attempted to determine whether the incorporation rates of ${ }^{3} \mathrm{H}$-thymidine (or ${ }^{3} \mathrm{H}$-leucine) could be used as a sensitive indicator of bacterial growth limitation by organic substrates in the natural environment.

In almost all experiments (except for fresh KIN-1), when substrates were added, there was an increase in dpm at $24 \mathrm{~h}$ compared to dpm at $1 \mathrm{~h}$ (Table 3). Samples which were stressed by preincubation usually showed a greater relative increase of $\mathrm{dpm}$ with the addition of substrates than fresh samples (Table 3 ).

Although increased rates of tracer incorporation were sometimes observed even after 3 or $6 \mathrm{~h}$, these occurred in all samples including the unsupplemented controls (except fresh KIN-2). Significant increases in tracer incorporation rates of supplemented samples relative to controls were in most cases only recorded after $24 \mathrm{~h}$. This time delay might be expected from the classical response of bacteria in chemostat shift-up experiments (Thimann 1964) and it also corresponds to observations on the growth responses of marine bacteria to amino acid supplements (Kirchman 1990). We emphasize that this relatively long lag in the response may be due to the fact that only the actual incorporation of radiotracer into macromolecules (DNA, proteins) was measured but not the total uptake of ${ }^{3} \mathrm{H}$ thymidine or ${ }^{3} \mathrm{H}$-leucine by the cells. Therefore, we suggest that if ${ }^{3} \mathrm{H}$-thymidine or ${ }^{3} \mathrm{H}$-leucine incorporation is used in order to assess the status of natural bacterial populations and their response to nutritional supplements, then preincubation times of $24 \mathrm{~h}$ with the substrates are necessary before a response can be measured.

${ }^{3} \mathrm{H}$-leucine incorporation rates usually showed a greater relative response (dpm at $24 \mathrm{~h}: \mathrm{dpm}$ at $1 \mathrm{~h}$ ) to the addition of organic substrates than ${ }^{3} \mathrm{H}$-thymidine (Table 3). Leucine incorporation tracks the synthesis of cellular protein, in contrast to ${ }^{3} \mathrm{H}$-thymidine incorporation, which is mainly indicative of cellular DNA replication. Protein synthesis would be expected to react more rapidly than that of DNA in a situation where cells were passing from a growth-limited to an activegrowth state (Simon \& Azam 1989, Chin-Leo \& Kirchman 1990).

The relative response of natural bacterial samples to added substrates after $24 \mathrm{~h}$ was generally greater in terms of changes observed in ${ }^{3} \mathrm{H}$-thymidine (or ${ }^{3} \mathrm{H}$ leucine) incorporation than in terms of cell numbers (compare Tables 2 and 3). It appears, therefore, that following the changes in radiotracer incorporation in aquatic bacteria can be a reasonably sensitive method for determining the impact of environmental perturbations such as organic matter inputs. Our limited experiments in Kiel waters suggest that ${ }^{3} \mathrm{H}$-leucine might be the preferred tracer. This approach might be conveniently used to monitor the nutritional status of aquatic bacteria seasonally in a given environment, or for comparative studies in different water bodies.

\section{Selection of bacterial populations adapted to added substrates}

In our experiments, it is unclear whether the increases observed in bacterial numbers or in radiotracer incorporation after $24 \mathrm{~h}$ were due to cell replication by all or most of the bacterial cells initially present, or whether the addition of substrate selected for a bacterial population specifically adapted for growth on that substrate. Our observation is that all added substrates stimulated bacterial growth after $24 \mathrm{~h}$ of incubation. Several investigators have reported that autochthonous aquatic bacterial populations appear to be adapted to exploit easily degradable substrates at any given time (e.g. Hoppe 1978). However, the strength of response towards the different substrate additions in our experiments varied considerably. Several explanations may be given to explain this phenomenon. (1) The total bacterial population is composed of several sub-populations of different size and activity with respect to the exploitation of a specific substrate enrichment. (2) Most bacteria of the total population are adapted to use easily degradable substrates; in this case the strength of response would depend on the nutritional value and energy content of the added compound. The strong responses towards 
glucose in preincubated Kiel water and in the preincubated series of KIN-1 may support this explanation. (3) Bacterial $\mathrm{Km}$-specialists taking advantage of the relatively high concentration of added substrates may have grown in the experiments, but with different intensities. Multiple transport kinetics for substrates such as glucose (Azam \& Hodson 1981) and leucine (Hagström et al. 1984) have been detected in natural plankton assemblages but it remains uncertain whether, under natural conditions, these mechanisms can be effective. However, if even transiently elevated concentrations of substrates can occur in microniches (Azam \& Cho 1987), selective uptake and growth processes could function as an important means to maintain physiologically diverse populations of bacteria in the environment.

\section{Prediction of bacterial growth rates by ${ }^{3} \mathrm{H}$-thymidine and ${ }^{3} \mathrm{H}$-leucine methods}

Both the ${ }^{3} \mathrm{H}$-thymidine and ${ }^{3} \mathrm{H}$-leucine methods were originally developed in order to provide estimates of bacterial production, expressed as the rate of net increase in cell numbers over time. Both methods depend critically on empirically based conversion factors, which in the case of thymidine may vary as much as 10-fold (Coveney \& Wetzel 1988, Smits \& Riemann 1988, Simek \& Straskrabova 1992).

In order to examine the reliability of these radiotracer methods as predictors of bacterial production we compared increases in cell numbers (direct counts) over $24 \mathrm{~h}$ with those inferred by the ${ }^{3} \mathrm{H}$-thymidine and ${ }^{3} \mathrm{H}$-leucine incorporation rates measured at $1 \mathrm{~h}$ after substrate addition (Table 4). To assess the validity of the results, it must be kept in mind that the uptake of radioactively labelled compounds can be measured with much higher sensitivity than microscopic changes in cell numbers or size. For 5 out of 6 cases using ${ }^{3} \mathrm{H}$ thymidine, there was a reasonable $( \pm 50 \%$ ) correspondence for the values observed in unsupplemented controls (preincubated Kiel water was the exception). In contrast, for supplemented samples, there was a tendency for the predicted production values to underestimate the observed bacterial production, often considerably. This finding was not unexpected because the utilization of added substrates by the natural bacterial populations probably caused changes in growth rates during the 24 h of incubation. Coveney \& Wetzel (1988) and Riemann et al. (1987) have also shown experimentally that nutrient additions to a given natural bacterial population may require higher thymidine conversion factors (cells per mole) to correspond with the observed cell increases. It could be speculated that predictions of bacterial growth by using biomass instead of cell number increases would provide more realistic results. Therefore we also compared microscopically observed biomass increases over $24 \mathrm{~h}$ to biomass increases predicted by ${ }^{3} \mathrm{H}$-leucine uptake at $1 \mathrm{~h}$. However, the results were generally not better than those calculated on the basis of cell numbers.

There was no distinct pattern of good or bad correspondence for any of the added substrates. Results from the preincubated Kiel experiments were exceptionally poor because in 3 out of 6 treatments radiotracer uptake occurred even though cell numbers decreased over $24 \mathrm{~h}$. But in this case, as noted above, there was a response in cell volume to supplements that was not reflected in the 'predictions' given in Table 4.

These results, although based on relatively few observations, suggest that the ${ }^{3} \mathrm{H}$-thymidine method can give reasonable predictions of bacterial growth rates when the empirical conversion factors are well characterized for a given aquatic environment. However, this may not hold when bacterial populations, especially if growth-limited, are subject to pulses of nutrients such as may be introduced by upwelling events or excretions from metazoans and phytoplankton. A similar conclusion is also probably true for ${ }^{3} \mathrm{H}$ leucine, although our present data are inadequate to prove this. In conclusion, radiotracer methods using ${ }^{3} \mathrm{H}$-thymidine or ${ }^{3} \mathrm{H}$-leucine are appropriate for the determination of momentary bacterial growth; however, extrapolation of values from short-term growth experiments to longer periods of time may introduce uncertainties due to the time lag of bacterial response to prevailing or changing nutrient regimes.

Acknowledgements. We thank B. Kaplan, R. Koppe and M. Mehrens for skilled technical assistance and S. Chava and S. Heise for making the bacterial counts. We also thank the reviewers for their critical comments, which greatly helped to improve this paper. This work was partly accomplished during a stay by $T$ Berman as Visiting Researcher at the Institut für Meereskunde an der Universität Kiel. This is a contribution of IOLR, which was supported in part by funding from the Israel Ministry of Energy and Infrastructure and the Israel Water Commissioner.

\section{LITERATURE CITED}

Azam, F., Cho, B. C. (1987). Bacterial utilization of organic matter in the sea. In: Fletcher, M., Gray, T. R. G., Jones, J. G. (eds.) Ecology of microbial communities. Cambridge Univ. Press, Cambridge, p. 261-281

Azam, R., Hodson, R. E. (1981). Multiphase kinetics for D-glucose uptake by assemblages of natural marine bacteria. Mar. Ecol. Prog. Ser. 6: 213-222

Bratbak, C. (1985). Bacterial biovolume and biomass estimation. Appl. environ. Microbiol. 49: 1488-1493

Chin-Leo, G., Kirchman, D. L. (1990). Unbalanced growth in natural assemblages of marine bacterioplankton. Mar. Ecol. Prog. Ser. 63: 1-8 
Chróst, R. J. (1991). Environmental control of the synthesis and activity of aquatic microbial ectoenzymes. In: Chróst, R. J. (ed.) Microbial enzymes in aquatic environments. Springer-Verlag, New York, p. 29-59

Chróst, R. J., Münster, U., Rai, H., Albrecht, D., Witzel, P. K., Overbeck, J. (1989). Photosynthetic production and exoenzymatic degradation of organic matter in the euphotic zone of a eutrophic lake. J. Plankton Res. 11: 223-242

Coveney, M. F., Wetzel, R. G. (1988). Experimental evaluation of conversion factors for the $3 \mathrm{H}$-thymidine incorporation assay of bacterial secondary productivity. Appl. environ. Microbiol. 54: 2018-2026

Fuhrman, J. A., Azam, F. (1982). Thymidine incorporation as a measure of heterotrophic bacterioplankton production in marine surface waters. Evaluation and field results. Mar. Biol. 66: 109-120

Gocke, K., Kremling, K., Osterroth, C., Wenck, A. (1987). Short-term fluctuations of microbial and chemical variables during different seasons in coastal Baltic waters. Mar. Ecol. Prog. Ser. 40: 137-144

Güde, H. (1986). Loss processes influencing growth of planktonic bacterial populations in Lake Constance. J. Plankton Res. 8: 795-810

Hagström, A., Ammermann, J. W., Henrichs, S., Azam, F. (1984). Bacterioplankton growth in seawater. II. Organic matter utilization during steady-state growth in seawater cultures. Mar. Ecol. Prog. Ser. 18: 31-39

Harder, W., Bijkhuizen, L. (1983). Physiological responses to nutrient limitation. A. Rev. Microbiol. 37: 1-23

Hobbie, J. E., Daley, R. J., Jasper, S. (1977). Use of nuclepore filters for counting bacteria by fluorescence microscope. Appl. environ. Microbiol. 33: 1225-1228

Hollibaugh, J T. (1988). Limitations of the $\left[{ }^{3} \mathrm{H}\right]$ thymidine method for estimating bacterial production due to thymidine metabolism. Mar. Ecol. Prog. Ser. 43: 19-30

Hoppe, H.-G. (1978). Relations between active bacterial and heterotrophic potential in the sea. Neth. J. Sea Res. 12: $78-98$

Hoppe, H.-G. (1983). Significance of exoenzymatic activities in the ecology of brackish water: measurements by means of methyl-umbelliferyl substrates. Mar. Ecol. Prog. Ser. 11: $299-308$

Karl, D. M. (1982). Selected nucleic acid precursors in studies of aquatic microbial ecology. Appl. environ. Microbiol. 44: $891-902$

Kirchman, D. L. (1990). Limitation of bacterial growth by dissolved organic matter in the subarctic Pacific. Mar. Ecol. Prog. Ser. 62: 47-54

Kirchman, D. L., Knees, E., Hodson, R. E. (1985). Leucine incorporation and its potential as a measure of protein synthesis by bacteria in natural aquatic systems. Appl. environ. Microbiol. 49: 599-607

This article was presented by G. Rheinheimer, Kiel, Germany
Kjelleberg, S., Hermansson, M. (1984). Starvation induced effects on bacterial surface characteristics. Appl. environ. Microbiol. 48: 497-503

Kjelleberg, S., Hermansson, M., Mårdén, P. (1987). The transient phase between growth and nongrowth of heterotrophic bacteria, with emphasis on the marine environment. A. Rev. Microbiol. 41. 25-49

Lenz, J. (1977). Hydrographic conditions In: Rheinheimer, G. (ed.) Microbial ecology of a brackish water environment. Springer-Verlag, Berlin, Heidelberg, New York, p. $12-25$

Mårdén, P., Tunlid, A., Malmcrona-Friberg, K., Odham, G. Kjelleberg, S. (1985). Physiological and morphological changes during short term starvation of marine bacterial isolates. Archs Microbiol 142: 326-332

Morita, R. Y. (1986). Starvation-survival. The normal mode of most bacteria in the ocean. Proc. IV ISME, p. 242-248

Münster, U., Chróst, R. J. (1990). Origin, composition, and microbial utilization of dissolved organic matter. In: Overbeck, J., Chróst, R. J. (eds.) Aquatic microbial ecology: biochemical and molecular approaches. Springer-Verlag, New York, p. 8-46

Pace, M. L. (1988). The problem of bacterial death rates Hydrobiologia 159: 41-49

Porter, K. G., Feig, Y. S. (1980). The use of DAPI for identifying and counting aquatic microflora. Limnol. Oceanogr 25: $943-948$

Riemann, B., Björnsen, P. K., Newell, S., Fallon, R. (1987). Calculation of cell production of coastal manine bacteria based on measured incorporation of $\left[{ }^{3} \mathrm{H}\right]$ thymidine Limnol. Oceanogr. 32: $471-476$

Serruya, C. (ed.) (1978). Lake Kinneret. Monographicae biologicae. Dr. Junk Publishers, The Hague

Simek, K., Straskrabova, V. (1992). Bacterioplankton production and protozoan bacterivory in a mesotrophic reservoir J. Plankton Res. 14: 773-787

Simon, M., Azam, F. (1989). Protein content and protein synthesis rates of planktonic marine bacteria. Mar. Ecol. Prog. Ser. 51: 201-213

Smits, J. D., Riemann, B. (1988). Calculation of cell production from ${ }^{3} \mathrm{H}$-thymidine incorporation with freshwater bacteria. Appl. environ. Microbiol 54: 2213-2219

Thimann, K.V. (1964). The life of Bacteria, 2nd edn. Macmillan, New York

Toolan, T., Wehr, J. D., Findlay, S. (1991). Inorganic phosphorus stimulation of bacterioplankton production in a mesoeutrophic lake. Appl. environ. Microbiol. 57: 2074-2078

Wicks, R. J., Robarts, R. D. (1987). The extraction and purifjcation of DNA labelled with [methyl- ${ }^{3} \mathrm{H}$ ]-thymidine in aquatic production studies. J. Plankton Res. 9: 1159-1166

Zimmermann, R., Meyer-Reil, L.-A. (1974). A new method for fluorescence staining of bacterial populations on membrane filters. Kieler Meeresforsch. 30: 24-27

Manuscript first received: May 11, 1993

Revised version accepted: September 9, 1993 